\title{
Estudos organizacionais no Brasil: do futuro que queremos e do futuro que teremos ${ }^{1}$
}

\author{
João Marcelo Crubellate*
}

\section{Resumo}

Este breve texto procura mostrar algumas das condições institucionais nas quais se desenvolvem os estudos organizacionais no Brasil, abordando tanto os principais entraves e exigências estruturais quanto as respostas dos pesquisadores da área a essas condições. À luz das circunstâncias vividas por uma personagem da peça Rinoceronte, de Eugéne Ionesco, acredito ser apropriado descrever a situação atual dos pesquisadores da área como a de rinocerontes numa encruzilhada entre a cômoda posição de iguais, num mundo de rinocerontes, e a luta para atingir alguma originalidade e, simultaneamente, alguma relevância universal para seus estudos.

Palavras chave: estudos organizacionais; pesquisa; organizações.

\begin{abstract}
This brief text intends to discuss some of our institutional conditions related to the organization studies in Brazil. It discusses not only the main problems and structural demands but also how the researchers in this field face such questions. Based on Éugéne Ionesco's play Rhinoceros, I believe that is possible to describe researchers' present dilemma as that of been at a crossroads: facing a comfortable position of been similar to the others, in a world of rhinos, or struggle to achieve some originality and, at the same time, universal relevance in their studies.
\end{abstract}

Key words: organization studies; research; organizations.

No Brasil, o passado recente da área de estudos organizacionais parece ter sido marcado pela evolução, ao menos, em termos de formalização do campo. Em 1998, o Encontro da Associação Nacional dos Programas de Pós-Graduação (Enanpad) já contava com duas áreas vinculadas aos estudos organizacionais: a de organizações e a de organizações/estratégia (administração estratégica, a partir de 1999). Em 2000, é realizado o $1^{\underline{0}}$ Encontro Nacional de Estudos Organizacionais (Eneo), em Curitiba. No ano seguinte, o campo se divide novamente no Enanpad, acrescendo-se a área de organizações/comportamento organizacional. Em 2002 ocorre o segundo Eneo, em Recife, e em 2004, o terceiro encontro. Além disso, observa-se o crescimento quantitativo da produção acadêmica nacional - cujo indício mais evidente parece ser o número cada vez maior de artigos apresentados nesses eventos -, além da crescente participação de acadêmicos brasileiros da área em congressos e eventos internacionais. Também não se pode desconsiderar a abertura de novos programas de pós-graduação centrados em estudos organizacionais, seja como sua área principal ou como uma de suas linhas de pesquisa.

Aparentemente são indícios de que apenas se está construindo uma estrutura institucional favorável ao desenvolvimento dos estudos organizacionais no país. Cabe ressaltar que o uso do termos "apenas" não significa desmerecer o esforço pelo que já foi conquistado. Entretanto, afirmar que as condições institucionais são cada vez mais favoráveis ao desenvolvimento dos estudos organizacionais não quer dizer que se tenha tudo o que é necessário para consolidar a área. Ainda que o ritmo de sua expansão e

\footnotetext{
${ }^{1}$ Texto apresentado na mesa-redonda "O futuro dos estudos organizacionais brasileiros: debate sobre a visão dos novos entrantes do campo", durante $03^{0}$ Eneo - Encontro de estudos organizacionais, Atibaia (SP), jun. 2004.

" Doutor em Administração pela EAESP/FGV. Professor da PPA-UEM/UEL. E-mail: jmcrubellate@ terra.com.br. Endereço: Rua Ana Cordeiro Dias, 368 - Cidade Nova - Maringá - PR - CEP P87.023-100.
}

Artigo recebido em setembro de 2005 e aceito para publicação em novembro de 2005 
formalização deva ser mantido, as condições vigentes ainda são insuficientes e demandam respostas apropriadas para que se reverta esse quadro e a área de estudos organizacionais se consolide como um campo de produção de conhecimento efetivamente relevante no Brasil.

O melhor caminho para isso é produzir conhecimento de interesse e original, calcado na realidade nacional e que, simultaneamente, tenha importância internacional. Portanto, é necessário discutir, inicialmente, nossa tradição de pesquisa, que é uma tradição ainda em construção. Uma característica particularmente evidente pelo fato de que os nossos cursos de pós-graduação - especialmente, os de doutorado - parecem se ressentir de maior foco tanto na formação para a pesquisa quanto na questão do conteúdo. Outro problema, é o excesso de disciplinas, a falta de definição da função social da pós-graduação - novamente, os doutorados em particular -, com modelos de aula baseados mais na transmissão de informação do que na discussão do conhecimento produzido pelos próprios professores/pesquisadores (como se a pós-graduação fosse continuação da graduação), dentre outras questões.

Alguns desses problemas, por mais paradoxal que seja, têm relação com o recente esforço pela melhora da produção nacional na área. Apesar de louvável, o esforço por uma maior quantidade de artigos nacionais, da forma como geralmente ocorre, pode ser uma resposta pelo menos parcialmente equivocada às atuais exigências quanto à pós-graduação no país, até porque inverte seu propósito. A publicação deveria ser resultado da pesquisa. Publicar muito deveria ser conseqüência de pesquisar muito, e não um fim em si mesmo. Temos aqui um exemplo do "paradoxo das conseqüências".

Além disso, outro problema aparentemente relacionado com essas questões é a necessidade de continuidade e aprofundamento das pesquisas. A excessiva demanda por publicação - ou, a interpretação que temos dado a essa exigência - parece resultar na falta de foco em pesquisas, isto é, na constante mudança de nossos objetos de estudo, nossas perspectivas e nossas teorias, sem que nos aprofundemos o suficiente em qualquer um desses objetos, perspectivas ou teorias. Esse aspecto parece ser um dos pontos mais críticos do campo dos estudos organizacionais, exatamente em decorrência da amplitude de fenômenos a ele relacionados.

Aqui temos que fazer - principalmente nós, os novos entrantes - um exame de nossas intenções, à luz da atitude defendida por Weber (1989)

aquele a quem falta a capacidade de, por assim dizer, pôr antolhos em si mesmo, e de convencer-se de que o destino de sua alma depende de ser correta sua interpretação particular de determinada passagem de um manuscrito [por exemplo], estará sempre alheio à ciência e à erudição.(...). Sem essa preciosa intoxicação, (...) a ciência não é sua vocação, e você deve fazer alguma outra coisa.

Também gostaria de citar o que costumava dizer o professor Tragtemberg, lembrado pela professora Maria Éster de Freitas, numa de suas aulas: "para cavar fundo, é necessário cavar no mesmo lugar". Produzindo esparsa e não sistematicamente, parece pouco provável que consigamos desenvolver conhecimento relevante.

Esses problemas talvez fossem amenizados se, ao lado dos critérios quantitativos de avaliação dos cursos de pós-graduação, tivéssemos também critérios qualitativos. Não é inválida a suposição de que o foco no desenvolvimento quantitativo de uma área levará ao seu desenvolvimento qualitativo, salvo talvez por suas consequiências inesperadas. Esse parece ser o caso da aquiescência demasiada à exigência de produção de artigos, livros etc., bem como sua inversão simbólica, isto é, a alteração do significado originalmente pretendido, para usar uma noção institucional de importância cada vez maior. Imaginar quais seriam esses critérios qualitativos é, de fato, um desafio.

Todas essas questões, se resolvidas, implicariam condições institucionais mais apropriadas ao desenvolvimento dos estudos organizacionais no Brasil. Contudo, do futuro que queremos ao futuro que de fato teremos, é preciso dar um passo fundamental: os estudos organizacionais no Brasil precisam torna-se de fato brasileiros, encontrar sua originalidade, sem perder a vocação universal própria dessa área. A título de 
ilustração, cabe citar um trecho da peça Rinoceronte, de Ionesco (1994), onde a personagem principal, Bérenger, lamenta sua "infeliz" e irreversível situação de ser humano convicto:

Ah, como eu gostaria de ser como eles [as demais pessoas que se transformaram em rinocerontes]. (...). Há um certo atrativo no canto deles, um pouco rude, mas mesmo assim é atraente! (...). Ah, como eu me arrependo. Devia ter seguido todos eles, enquanto era tempo. Agora é tarde demais! Infelizmente, eu sou um monstro, eu sou um monstro! Infelizmente, nunca serei rinoceronte, nunca, nunca. Nunca mais poderei mudar. (...). Como eu sou feio! Infeliz daquele que quer conservar a sua originalidade! (Tem um sobressalto brusco): Muito bem! Tanto pior! Eu me defenderei contra todo o mundo!(...). Sou o último homem, hei de sê-lo até ao fim! Não me rendo!

Nosso dilema guarda paralelos, mas também diferenças, em relação ao dilema da personagem de Ionesco: Bérenger luta por causa da tensão entre o desejo de ser igual aos demais, a vergonha de ser diferente e a impossibilidade de ceder à mudança que o faria igual a todos os demais - um rinoceronte. Resolve, então, assumir a originalidade em face dos demais transformados.

A mensagem de Ionesco é clara. A originalidade pode ser perigosa, difícil de ser mantida e até vergonhosa, mas é necessária. Os estudos organizacionais brasileiros não têm uma originalidade a manter, mas a conquistar, e isso não dependerá apenas de condições estruturais apropriadas, mas também da vontade dos pesquisadores da área. Vontade para, ao contrário do Bérenger de Ionesco, que luta para aceitar e manter sua condição de diferença num mundo de rinocerontes, sairmos da condição de rinocerontes e alcançarmos a originalidade.

Acredito que Ionesco também nos faz um alerta: a mudança nem sempre gera a originalidade - pode mesmo levar à sua perda. Para onde caminhamos nós, estudantes das organizações? No futuro, nossas pesquisas terão algo de original, ou definitivamente nos resignaremos à confortável posição de rinocerontes? 


\section{Referências bibliográficas}

WEBER, M. Sobre a universidade. São Paulo: Cortez, 1989.

IONESCO, E. Rinoceronte. São Paulo: Agir, 1994. 